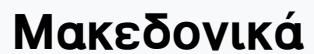

Tó. 39, Ap. 1 (2010)

MAKGAONIKA

ГYTГPAMMA ПEPIOAIKON

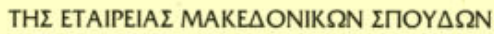

TOMOE TPIAKOETOE ENATOE

2010-2012

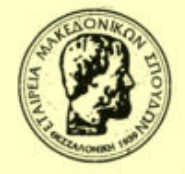

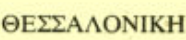

2013
Some further fragments of the chronicle of Manasses

Dean Sakel

doi: $\underline{10.12681 / \text { makedonika.709 }}$

Copyright $\odot 2015$, Dean Sakel

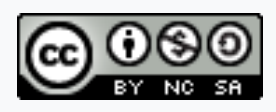

Ađ¿sı Xpńбns Creative Commons Attribution-NonCommercial-ShareAlike 4.0.





https://doi.org/10.12681/makedonika.709 


\section{SOME FURTHER FRAGMENTS OF THE CHRONICLE OF MANASSES}

Cod. Athous 2789 Docheiariou 115, containing miscellanea, is made up of two manuscript sections, one of the fifteenth century (which forms the greater part of the codex) and another of the sixteenth ${ }^{1}$. It contains an entry (n. 32 according to the Lam-

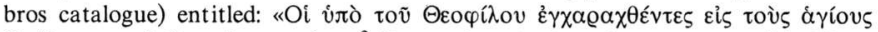

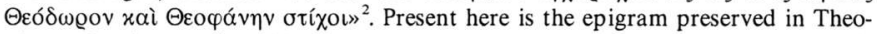
phanes Continuatus (and his known user Skylitzes, whence it also passed elsewhere), which gives the letters said to have been inscribed on the foreheads of the said martyrs on the orders of the ninth-century Byzantine Iconoclast emperor Theophilus ${ }^{3}$. The epigram is however followed in the Docheiariou manuscript by twenty-four verses from the chronicle of Manasses, in particular verses $4812-4813$ and $4826-4847^{4}$. The arrangement is based on the layout of verses $4826-4847$, with verses $4812-4813$ having been incorporated between verses 4830-4831. A few changes have been made to the text.

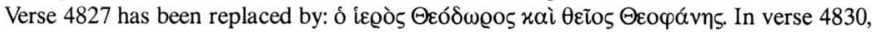

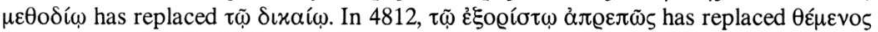

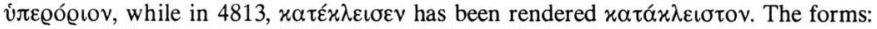

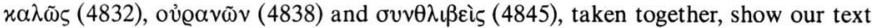
to derive from the recension of Manasses present in Cod. Vaticanus graecus 1409, which is of the late thirteenth century.

The epigram and the verses from Manasses are present in the section of Cod. Docheiariou 115 dating from the fifteenth century ${ }^{5}$. Cod. Athous 492 Konstamonitou 56 , from the eighteenth century, and containing most, though not all, the fifteenth-century section of Cod. Docheiariou 115, also contains the same texts. ${ }^{6}$ We have therefore two further, albeit partial and reworked, representatives of Manasses to add to the 115 already known, as well as two further cases of the epigram, from whichever part of the tradition of Theophanes Continuatus it may derive.

Istanbul

DEAN SAKEL

1. S. P. Lambros, Catalogue of the Greek Manuscripts on Mount Athos, Cambridge, vol. 1, 1895 (repr. Amsterdam 1966), pp. 250-251. The second part of the codex is stated in the catalogue to date from the fourteenth century, evidently in error.

2.. Ibidem, p. 251.

3. Theophanes Continuatus, Ioannes Cameniata, Symeon Magister, Georgius Monachus, ex recognitione Immanuelis Bekkeri, Bonn, 1838, pp. 105-106' Ioannes Scylitzae Synopsis Historiarum, editio princeps, recensuit Ioannes Thurn, Berlin - New York 1973, pp. 62-63.

4. Constantini Manassis Breviaruim Chronicum, recensuit Odysseus Lampsidis, pars prior Praefationem et Textum Continens, Athens 1996, 262-263.

5. Cod. Docheiariou 115 , p. 220 . This item is wrongly stated by the catalogue to belong to the fourteenth (actually the sixteenth)-century section of the codex.

6. Lambros, op.cit., p. 40. Cod. Konstamonitou 56, f. $89 \mathrm{r}-89 \mathrm{v}$. The description of the Lambros catalogue is brief and inaccurate, in contrast to Cod. Docheiariou 115, whose description is mostly representative of its content. In this manuscript, the item bears the overall title «'Ex

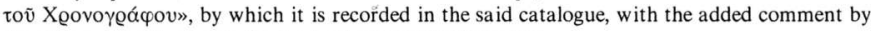

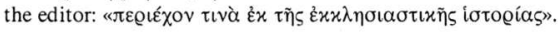

